\title{
Memoria poética e infancia en la escritura de Antonia Torres y Alejandra del Río ${ }^{1}$
}

\section{Poetic Memory and Childhood in the Writings of Antonia Torres and Alejandra del Río}

\author{
Alicia Salomone \\ Universidad de Chile \\ aliciasalomone@gmail.com
}

\author{
Karen Cea \\ Universidad de Chile \\ karen.cea.p@gmail.com
}

\section{Resumen}

Este trabajo explora la relación entre poesía y memoria en la escritura de mujeres del Cono Sur, abordando en particular dos textos de poetas chilenas de la llamada Generación del 90: Las estaciones aéreas, de Antonia Torres, y Material mente diario, de Alejandra del Río. Este estudio, que se lleva a cabo desde un enfoque comparativo, tiene por objetivo hacer un análisis de las estrategias discursivas a través de las cuales estos textos configuran sus respectivas poéticas de la memoria, donde cobra relevancia la relación que se establece entre memoria e infancia. Metodológicamente, este análisis procede desde una perspectiva que busca vincular el estudio de los textos poéticos con los contextos de producción de los cuales ellos emergen.

Palabras clave: poesía, memoria, Cono Sur, literatura chilena, escritura de mujeres, infancia.

\begin{abstract}
This article explores the relationship between poetry and memory in women's writing from the Southern Cone, focusing on texts by two Chilean poets who belong to the $90 \mathrm{~s}$ Generation: Las estaciones aéreas by Antonia Torres and Material mente diario by Alejandra del Río. This study is carried out through a comparative approach and aims to analyze the discourse strategies through which these texts shape their own poetics of memory, where relationship between memory and childhood becomes relevant. Methodologically, this analysis is developed from a perspective that aims to link the study of poetic texts with the production contexts from which they emerge.
\end{abstract}

Keywords: Poetry, Memory, Southern Cone, Chilean Literature, Women’s Writing, Childhood.

1 Este trabajo se realiza en el marco del desarrollo del Proyecto Fondecyt Regular N ${ }^{\circ} 1110083$ : "Memoria y escritura poética de mujeres en el Cono Sur de América, 1972-2010". 


\section{Introducción}

En las últimas décadas hemos sido testigos del interés que genera a nivel mundial la recuperación de memorias del pasado y su estudio, lo que ha dado lugar al desarrollo de distintas aproximaciones críticas. Así, se ha configurado una filosofía o fenomenología de la memoria, una sociología de la memoria, una historia de la memoria y una estética de la memoria. Este último campo reflexivo se pregunta por las condiciones y modos a través de los cuales el arte, y en particular la literatura, crea lenguajes que, tensionando al extremo los límites de la representación, logran dar cuenta de experiencias traumáticas individuales y colectivas que parecen sobrepasar los recursos de comprensión e ideación humanas.

Estas discusiones refractan en el Cono Sur de América sobre todo desde mediados de los años noventa, cuando se reinstalan las demandas de justicia frente a las violaciones de derechos humanos perpetradas por las dictaduras militares de las décadas precedentes, que habían dejado un saldo desolador de miles de personas muertas, desaparecidas, torturadas y exiliadas. Esas demandas buscaban, por un lado, revertir la impunidad impuesta por la aplicación de amnistías e indultos, y por otro, ponían en discusión una verdad dolorosa de la que una parte de la sociedad parecía no querer hacerse cargo.

En el caso de Chile, la transición pactada con los militares representó serias cortapisas al intento de lograr una democratización profunda, lo que derivó en que importantes parcelas del poder quedaran en manos de los antiguos golpistas y, asimismo, en el escaso cuestionamiento a la reconversión neocapitalista iniciada por el régimen. En ese Chile, al que Tomás Moulián describía en 1997 como un país con compulsión al olvido, el pasado reciente parecía encapsulado y ajeno:

\footnotetext{
Chile Actual proviene de la fertilidad de un "ménage a trois", es la materialización de una cópula incesante entre militares, intelectuales neoliberales y empresarios nacionales y transnacionales. Coito de diecisiete años que produjo una sociedad donde lo social es construido como natural y donde (hasta ahora) solo hay paulatinos ajustes. [...] En la Matriz de una dictadura terrorista devenida dictadura constitucional se formó el Chile Actual, obsesionado por el olvido de esos orígenes (Moulián 18).
}

La detención de Augusto Pinochet en Londres, en octubre de 1998, así como su posterior juicio y condena torció, sin embargo, ese rumbo. En un escenario nacional alicaído, esa detención produjo el estallido de memorias largamente subsumidas y abrió un debate tanto acerca de los crímenes de la dictadura como de los múltiples condicionamientos implicados en una transición a medias.

En este nuevo clima social se fue generando una reflexión intelectual que, desde la historia, la sociología y el arte ha venido acompañando la evolución de las llamadas "luchas por la memoria" (Jelin 42-3). En nuestro ámbito particular, el literario, esas tensiones también se expresaron y tomaron forma, en los años de posdictadura, en una producción que desde distintas modalidades textuales puso en acto sus respectivas elaboraciones acerca de lo acontecido en el pasado reciente. En el terreno de la crítica, por 
otra parte, esos procesos también fructificaron en un interés por comprender cómo las creaciones literarias, atendiendo a sus lenguajes y procedimientos específicos, estaban tomando posiciones entre las memorias en pugna.

Por nuestra parte, desde un proyecto que indaga en cómo la poesía, y en particular la poesía de mujeres del Cono Sur, se hace cargo de estas problemáticas, nos aproximamos aquí a la relación entre subjetividad, escritura y memoria desde la obra de dos poetas chilenas de la Generación del 90: Antonia Torres y Alejandra del Río. De la primera revisaremos su poemario de 1999, Las estaciones aéreas, y de la segunda, Material mente diario, 1998-2008, publicado en 2009, asumiendo un enfoque comparativo que se concentrará en las estrategias que dan forma a sus respectivas poéticas de la memoria, con especial referencia a la relación entre memoria poética e infancia.

En términos teórico-metodológicos, este estudio se apoya en reflexiones, entre ellas las de Paul Ricoeur (La memoria, la historia, el olvido), que operativizan la noción de memoria asumiéndola como un proceso mental de rememoración consciente del pasado, realizado por una persona en el presente, y que se traduce en discurso. Por otra parte, si bien la memoria es un proceso activo y personal, involucra dimensiones intersubjetivas, dado que las experiencias individuales se asientan en un sustrato cultural común y son expresadas en una lengua que suele ser la de la comunidad (Halwachs). Hay que tener presente, asimismo, que la memoria no solo es parcial y dinámica, sino que también contiene al olvido, así como la palabra involucra la presencia del silencio. En este sentido, los relatos sobre la memoria siempre están abiertos a su transformación y rearticulación, al tiempo que suelen implicar conflictos respecto de visiones del pasado que influyen en el modo como se evalúa el presente.

Por otra parte, han resultado útiles las propuestas de Gilda Waldman, quien resignifica para el Cono Sur las ideas de Marianne Hirsch sobre la diferencia entre memoria y posmemoria en el holocausto, con el objeto de llamar la atención sobre las memorias de personas nacidas durante o después de las dictaduras y que no estuvieron directamente implicadas en los eventos trágicos de las décadas del setenta y ochenta. No obstante, como advierte Waldman, la vivencia de un cierto trauma también aparece en estas generaciones. Pues si bien su discurso tiene rasgos diferentes del de sus mayores, trasluce cómo sus subjetividades también se vieron marcadas por esos hechos, ya sea a través de circunstancias que afectaron a esas personas en la infancia, por relatos familiares sobre situaciones que precedieron a sus nacimientos o, incluso, como miembros de una comunidad nacional que debió experimentar el impacto de la violencia represiva del Estado.

Dicho lo anterior, es posible acercarse a la pregunta central de este trabajo, que se refiere a cómo la poesía, desde su condición particular, contribuye a inscribir literariamente las memorias. Al respecto, recogemos lo planteado por Alicia Genovese ("Entre la ira y el arte del olvido: testimonio e imagen poética" 69-76), quien destaca el potencial de la imagen poética para evocar sensaciones y percepciones, superando los recursos de los géneros referenciales, tales como cartas, diarios íntimos o testimonios. Si bien para Genovese estos géneros fueron cruciales para instalar demandas de justicia, tienen limi- 
taciones para poner en palabras ciertas experiencias traumáticas, pues dejan la sensación, tanto en quien habla como en quien lee, de que hay algo esencial que no alcanza a ser dicho y que, por ende, permanece innombrado.

La imagen poética, en cambio, al manifestarse de modo metafórico, ofrece al hablante otras herramientas para expresar sus vivencias y otorgarles nuevos significados, eludiendo el rechazo que suele provocar la literalidad del testimonio. Como dice Genovese, la poesía logra ubicarse donde los lenguajes eficientes fracasan pues, como configuración abierta e imprevisible, e incluso por ser considerada socialmente intrascendente, impacta como un signo menos fácil de desautorizar (Genovese, Leer poesía 10). Situada en el espacio intersticial que otros géneros pasan por alto, opera desde un lenguaje opaco que se aparta de la norma lingüística y recupera lo no dicho, entendiéndolo como un silencio que es tachadura de sentido más que ausencia de palabra (Genovese, Leer poesía 19). Por otra parte, la mudez intencionada de la poesía promueve el hallazgo de la sintaxis y el ritmo adecuados, de la puntuación que se acomoda con la respiración, así como del tono, que operará como cámara de resonancia para la subjetividad (Genovese, Leer poesía 17). Así, exiliada de la lengua convencional, concluye Genovese, la poesía es capaz de recuperar el eco de un diálogo interno que remite al encuentro entre el hablante y ese mundo que será traspuesto al texto desde una captación eminentemente subjetiva (Genovese, Leer poesía 34).

A partir de las ideas que acabamos de reseñar, nos acercamos a los textos poéticos de Alejandra del Río y Antonia Torres, con el objeto de observar de qué forma se generan en ellos ciertas poéticas de la posmemoria, asumiendo la idea de poética, por una parte, como la impronta o estilo característico de cada autor/a, que conlleva una visión de mundo, y, por otra, una disposición metapoética que vuelve la mirada hacia la propia escritura y sus procedimientos. Como advierte Francisco Véjar (13) en relación con la poesía de los noventa, esta orientación no se dirige solo a reflexionar al interior del poema sobre el propio poema, sino también a indagar en la materialidad de un lenguaje con el que podría reconstruirse el puente (roto) hacia la comunidad.

\section{Antonia Torres y Alejandra del Río: dos mujeres entre náufragos}

Antonia Torres y Alejandra del Río integran una cohorte de poetas nacidos en Chile poco antes de o durante la dictadura y formados en la posdictadura, entre el clima represivo que caracterizó a la primera y el desánimo y la apatía que primó en la segunda². Se trata de una generación de poetas que se forman en las universidades, o que pasan por ellas, y

2 Francisca Lange, en su antología Diecinueve: (poetas chilenos de los noventa), incluye en esta generación a poetas nacidos entre los años 1967 y 1977. Por su parte, Magda Sepúlveda menciona en su estudio, entre otros, los siguientes nombres: Javier Bello, Matías Ayala, Andrés Anwandter, Germán Carrasco, Verónica Jiménez, Jaime Huenún, Alejandro Zambra, Armando Roa, Alejandra del Río, Marcelo Novoa, Kurt Folch, Rafael Rubio, Felipe Cussen, Yanko González y Antonia Torres. 
que comienzan a escribir en una época en que las posibilidades de publicación y circulación de textos poéticos eran restringidas. Según afirma Francisco Véjar, ellos acceden al espacio literario marcados por una tensión en la que se oponen el desencanto al deseo de soñar, el fulgor al desamparo, y terminan por instalar una apuesta colectiva, "aunque no todos la compartan del mismo modo ni mucho menos con los mismos fines" (11).

Javier Bello, tempranamente, se refiere a esta generación poética como los náufragos, considerando la relevancia que tiene en su poesía el motivo del viaje y la condición peregrina y buscadora de secretos y tesoros de los sujetos líricos. Por otra parte, los define como un grupo heterogéneo, que crea mundos cerrados y heterotópicos, los que traslucen, por un lado, su desconcierto ante el entorno, por otro, su desconexión con la tradición poética local, y, por último, una sensibilidad posmoderna que va a la par con la crisis de las narrativas emancipatorias y la individuación derivada de la masificación de relaciones mercantiles. Así, concluye Bello, estos poetas producen una poesía clausurada que se modela sobre fragmentos, construyendo imágenes escatológicas pobladas de restos, ruinas y fantasmas, al tiempo que instala una palabra que ha sido vaciada de formas $y$ sentidos (41-3).

Por su parte, Magda Sepúlveda señala la localización incómoda de esta generación, situada entre quienes comienzan a escribir en dictadura (Raúl Zurita, Elvira Hernández, Carmen Berenguer, Eugenia Brito, entre otros) y los ya reconocibles poetas de los 2000 (Pablo Paredes, Héctor Hernández, Gladys González, Paula Ilabaca, entre otros). Para Sepúlveda, la poesía de los noventa pone en escena a ciudadanos sin tiempo y sin historia, que han extraviado la bandera y el mapa, y que deambulan carentes de poder territorial por un universo simbólico disolvente y errático. De allí que los textos evidencien una sintomatología del extravío de referentes, un desconcierto que alcanza hasta el lenguaje, donde la presencia de silencios y blancos amenaza la estructura misma del poema. "En otras palabras, la sintomatología del desastre se apodera del discurso de los poetas del noventa" (Sepúlveda 83).

Por nuestra parte, no podemos sino relacionar los rasgos escriturales que señalan estos críticos con la centralidad que tiene, en estas generaciones poéticas, el intento de recuperar una memoria del pasado, trayendo al presente las ausencias, dolores y fantasmas adosados a la infancia y primera juventud. Se trata de una memoria personal traspasada de elementos que evocan una experiencia colectiva, que recurrentemente emerge como trunca o fracturada. Por otra parte, como sostiene Jorge Monteleone al observar la misma actitud en poetas argentinos, esa memoria no parece tener la legitimidad que podría proporcionarle una épica o herencia válida recibida de los ancestros, pues esta ya no existe o está desacreditada ${ }^{3}$. En estas condiciones, las memorias de esta generación

3 Monteleone señala esta sensibilidad en los poetas argentinos de los noventa al afirmar que el sujeto imaginario de su poesía suele ser un joven que se halla en un vacío de memoria y en consecuencia debe restaurar un relato de la historia donde la épica está ausente y la tradición anterior perdió su sentido o está clausurada. Carente de futuro, en el sentido utópico del término, se siente desclasado y a la vez sabe que su segura herencia fue la derrota de la generación que dio los pasos previos. 
poética tienden a adoptar el ropaje de un relato desmembrado, lleno de dudas y siempre provisorio, cuyo despliegue supone una exploración ardua por los escondites donde se aloja una subjetividad dolida.

En cuanto al lenguaje mismo, el sujeto que enuncia el discurso suele enfrentarse a la dificultad que supone ejecutar una praxis memoriosa a partir de una lengua que se resiste a inscribir una herida que apenas puede ser nombrada. Por otra parte, también implica llevar a cabo esta labor sin el respaldo de una tradición poética establecida, pues esta ya no se encuentra inmediatamente disponible y debe ser reconstruida a tientas. Quizás por eso, esta poesía tiende a asumir la modalidad de un rastreo reconstructivo o arqueológico de ciertos restos materiales y simbólicos, que son el insumo o anclaje básico a partir del cual este sujeto precario intentará (re)construirse desde la enunciación de su relato.

Los textos de Antonia Torres y Alejandra del Río, que revisaremos a continuación, se encuentran insertos en estas coordenadas. Tienen en común la explicitación de una poética de la memoria que las hablantes configuran desde una indagación profunda y lacerante en sus obsesiones, paisajes y recorridos interiores, teniendo en la mira una recreación personal que solo parece posible realizar en diálogo con la poesía. Pues, como dice Antonia Torres: "Más fácil es renunciar al pan que a las palabras,/ se nos advirtió" (24, destacado en el original). Desde ese lugar enunciativo, que recurre a una reapropiación abierta de la tradición poética local e internacional, tanto Torres como del Río construyen lenguajes que logran acompasar sus procesos subjetivos. En los textos, esos lenguajes escenifican una serie de acciones y transformaciones que se desarrollan en contacto estrecho con las fuerzas de la naturaleza, la que opera como una energía nutricia y reconstituyente que estimulará la resiliencia de las sujetos.

En la escritura de Antonia Torres, ese trayecto pasa por la realización de ciertos rituales en el agua y por su relación con la naturaleza chilena, y en particular sureña, sobre la cual la hablante irá proyectando sus vivencias interiores. En la de Alejandra del Río, se liga al vínculo de la hablante con una tierra que acoge y esconde tesoros, pero que también es capaz de estallar violentamente, arrojando lava volcánica como ella arroja palabras. En ambas poéticas, ese trabajo con el recuerdo hace posible la emergencia de lo que Paul Ricoeur ("Historia y memoria. La escritura de la historia y la representación del pasado"), retomando a Henri Bergson, denomina una memoria feliz, un concepto que alude a la recuperación de las imágenes que el dolor había obturado, permitiendo, de este modo, el inicio de la elaboración del trauma. Al respecto, dice Ricoeur:

El recuerdo es una operación compleja que puede tener éxito o no. Su éxito es el reconocimiento del recuerdo que Bergson convierte en la experiencia princeps en Materia y memoria [...] El reconocimiento aparece como un pequeño milagro, el de la memoria feliz, si se la compara con todas las dificultades que jalonan el recorrido del recordar ("Historia y memoria. La escritura de la historia y la representación del pasado" 9). 
Finalmente, estos procesos de rememoración desplegados en los textos no se pueden separar de la reflexión que las hablantes producen respecto del propio lenguaje, al que interrogan una y otra vez en torno a las posibilidades, límites y condiciones a través de las cuales tiene lugar la plasmación poética de sus respectivas memorias.

\section{Las estaciones aéreas: del ritual de la inmersión a la recuperación de la imagen-recuerdo}

La sujeto que habita Las estaciones aéreas, de Antonia Torres, es una hablante-mujer que, como anticipábamos, realiza un viaje, esencialmente personal, que proyecta sobre distintos espacios exteriores. Ella delimita su recorrido en el lapso que va desde la apertura al fin de una temporada; dos nombres que titulan las secciones del libro y que, a su vez, alumbran una serie de correspondencias entre ellas. La primera parte comienza con dos inmersiones en el río, que la hablante realiza como un rito iniciático y purificador a partir del cual puede dar curso a su trayecto; la segunda concluye con tres andares por la tierra. Al relacionar ambas secciones se observa una alternancia entre movimientos acuáticos y terrestres, entre el buceo en las profundidades y la recolección de objetos en la superficie, lo que permite vincular la descripción del paisaje con una subjetividad que afanosamente busca un sentido para sus hallazgos:

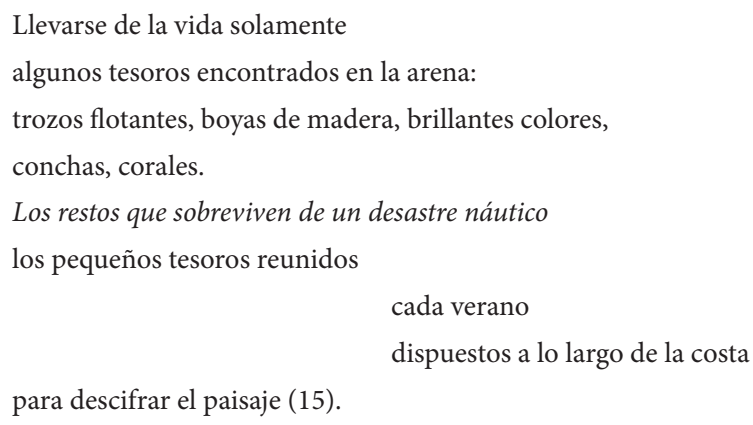

Esta referencia a los restos de un desastre náutico, así como a la labor arqueológica que realiza esta hablante ambulante y extranjera (22), según se autodefine a partir de las palabras de Antonio Cisneros, desde un comienzo orientan el libro hacia la recuperación de una memoria individual que no puede desligarse de una connotación de sentido colectivo. Esta línea se refuerza con la incorporación de tres textos epigramáticos, dos al inicio y uno al final, que por su localización enmarcan estructuralmente al texto. La primera de estas inscripciones presenta a la hablante en un entorno acogedor y en una actitud de laxo abandono que parece disponerla al goce dulce del ejercicio poético; un estado que deriva rápidamente hacia uno diferente, mediante la irrupción de una imagen que anuda su enunciación al proceso del recordar: 


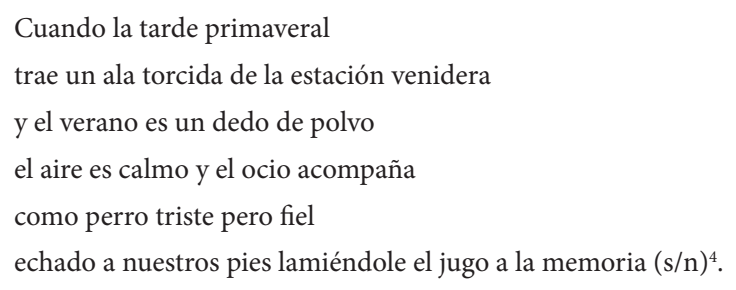

Si esta referencia remite a lo inminente de un proceso rememorativo que necesariamente tendrá lugar por medio del lenguaje, en tanto instrumento que permite dar cuenta de la vivencia de la hablante, un segundo epígrafe, en este caso de Eugenio Montale, viene a desestabilizar esa posibilidad:
[...] dan fe estas palabras mías
a un evento imposible, y lo ignoran

De este modo, a través de este enunciado irónico, que la hablante apropia a través de la cita, se cuestiona no solo la capacidad representativa del lenguaje y su ilusión testimonial, sino que también se pone en entredicho la capacidad cognitiva del sujeto que rememora, e incluso se hace inestable la entidad misma de aquello que se podría recordar ${ }^{5}$.

Tensionada entre la pulsión memoriosa y las dudas que parece provocarle este ejercicio, la hablante desplegará su trayectoria adoptando a la poesía como una herramienta expresiva y cognitiva que resulta afín al carácter de su indagación. Así, desplazándose entre el discurso consciente y la latencia inconsciente, figurativamente entre la tierra y el agua, la poesía le permitirá eludir toda identificación con un sujeto autoconsciente que ella no quiere ser, para dibujar, en cambio, otro tipo de subjetividad $y$, por ende, otra lengua: una voz que ella localiza en un espacio intermedio entre la vigilia y el sueño, y que aparece signada por el deseo, en tanto surge de su boca bajo la forma de "febriles delirios" (11).

De esa lengua, por otra parte, se derivará una poética que concibe al poema como un cazador oculto, que captura voces exteriores que la hablante recibe al oído como en un secreto y que plasma mediante un procedimiento de transcripción o traducción. Así, surge una palabra muda y sonora a la vez que, por entre los huecos que deja la disposición de los signos en la página, se cuela para nombrar lo que aún no tiene palabra: ese no dicho de la poesía que, para Alicia Genovese, remite a lo que los otros discursos dejan fuera, afirmando a la poesía como una fuerza de negatividad y resistencia (Leer poesía 19). Dice la hablante:

4 En la segunda edición del texto, de 2006, este verso largo se segmenta en dos: "echado a nuestros pies/ lamiéndole el jugo a la memoria", lo que, desde nuestra perspectiva, enfatiza el sentimiento memorioso que surge en la hablante de manera intempestiva.

5 En la segunda edición del libro, este epígrafe, ubicado inicialmente en segundo lugar, pasa a situarse en el primero, lo que interpretamos como una radicalización del escepticismo gnoseológico y ontológico que la hablante expresa a través de esta cita. 


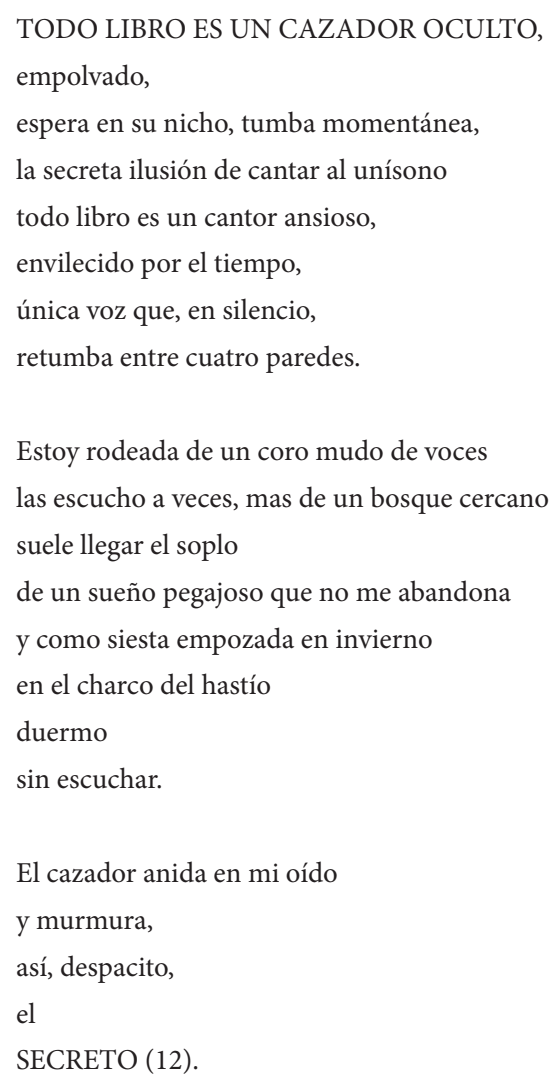

La escritura, como medio articulador de una poética de la memoria es, desde nuestra perspectiva, el eje sobre el que pivota el texto de Antonia Torres, y sobre el que reflexionará en distintos momentos y escenas que evidencian los múltiples caminos que puede asumir el recordar. Entre ellos, destaca una experiencia que resulta crucial y determina, asimismo, el temple introspectivo y el tono melancólico del texto. Se trata de la relación que liga a la hablante con la figura paterna, que aparece muchas veces aludida en el poemario, pero siempre como una presencia fantasmática. De ella poco sabemos, si bien se prefigura metonímicamente en la alusión a sus libros, en la imagen de la infancia como casa del poeta, y hasta en la referencia a una tradición literaria que opera como puente simbólico entre la hablante/poeta y ese padre/poeta que ya ha muerto. La emergencia de la imagen-recuerdo que ella finalmente logra conformar, tiene lugar a partir del hallazgo de una vieja fotografía que le ha tomado al padre en la infancia y que observa de forma distanciada, detectando el aspecto difuso y ausente de los personajes, así como la condición arbitraria de un procedimiento que devuelve escenas al azar.

Frente a esa supervivencia fantasmal del padre, a quien casi no puede reconocer en el retrato, la hablante opta por otra alternativa, volver sobre esa escena desde el recuerdo de su propia vivencia al momento de sacar la foto, trayendo al presente su emocionado 
respirar tras la lente y el modelado de las poses de los personajes al disponer la escena, para finalmente, recuperar su gozo tras el disparo que plasma la imagen que ha logrado perdurar en el tiempo. Así, ella contrapone dos modos diversos del recordar: por un lado, uno mecánico, literal, que solo puede entregar la evidencia de una ausencia, y otro que, por el contrario, le ofrece una vía rememorativa acorde a su posibilidad y a su deseo. Esto es, recuperar una imagen en la palabra, desde una subjetividad que, situada en el presente, recuerda y olvida, observa y selecciona, y logra asentar en el poema la huella de una vivencia significativa. Un modo que la hablante parece juzgar productivo para enfrentar, activa y creativamente, la elaboración de un duelo que es personal y también histórico:

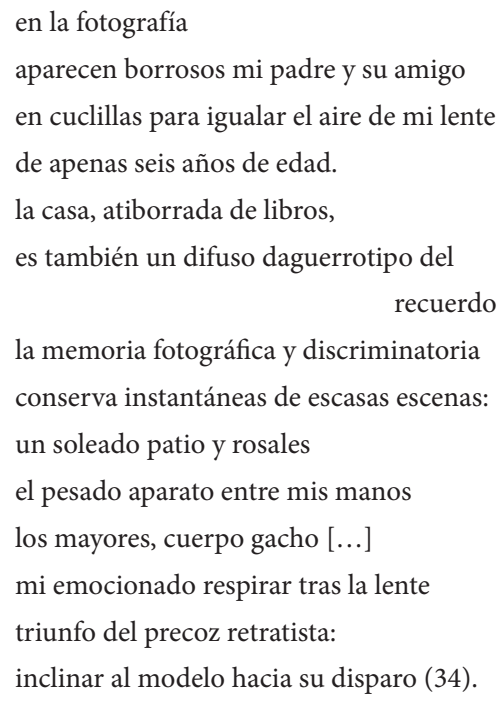

Como queda dicho, la problematización de la memoria y de los modos de representación confluyen en este poema y, de esta forma, también se indica el final del recorrido de la hablante a lo largo de su texto. Quizás por eso el último poema del libro no puede ser sino otro epígrafe, formalmente separado de los tres últimos andares; un epílogo que, en su modo conclusivo y circular, al tiempo que cierra esta exploración subjetiva y poética, anuncia el inicio de una nueva:

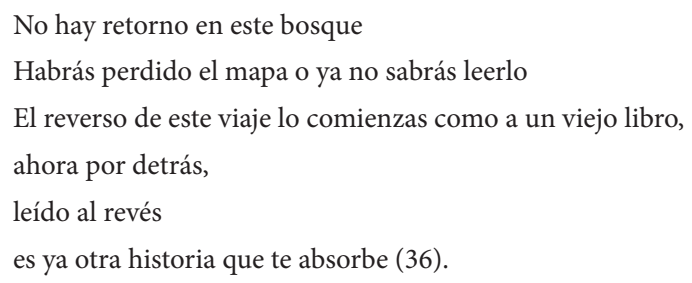




\section{Material mente diario, 1998-2008, de Alejandra del Río: pies que portan un camino de retorno}

La poética que construye Alejandra del Río en su texto entrega una configuración desmembrada de la memoria, que integra una serie de vivencias que han marcado en la infancia a la sujeto que enuncia: el impacto de la política, la compleja vida familiar, el dolor y la muerte, entre otras. Esa construcción, que remite a una historia signada por el trauma de una derrota ubicada en un pasado, que como herencia parental revierte sobre la hablante, se refracta en ciertas figuras que aparecen en los poemas, tales como el imbunche, el colgado o el decapitado. Ellas entregan claves de un relato que se irá develando en el recorrido del libro, cuyas secciones ("La mesa", "La mano", "Los pies" y "La ventana"), desde su denominación, aluden a la parcelación e incompletitud que caracterizará la representación. De este modo, no es un cuerpo completo el portador de la experiencia que se narra, sino que son solo los pies o la mano; y tampoco es una casa la que acoge a dicha sujeto, sino solo una ventana o una mesa, como dos signos que precariamente remiten al hogar y lo cotidiano. Aun así, ese núcleo doméstico es crucial para la hablante, pues lo identifica como propio, contraponiéndolo a esa casa entera que ve construirse en el presente del poema y que amenaza con borrar aquel territorio originario de la infancia. Frente a la casa nueva, aquellos cerros desolados, poblados de yuyos y conchales, escenario de los juegos de la niñez, se alzan como el lugar donde ella radica su principal referente identitario, mi único legado:

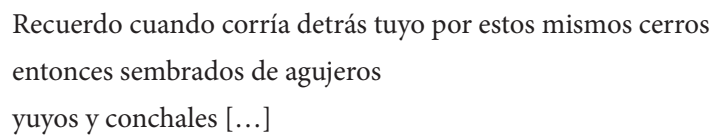

Están construyendo una casa en mi único legado (67).

Entre las figuras dibujadas en el libro, la del imbunche, descrita en el poema del mismo nombre, puede pensarse como una metáfora que pone en abismo la totalidad del poemario, ya que simboliza la oscilación entre lo que se muestra y lo que se esconde, lo que se dice y lo que se calla. En este sentido, vale la pena recordar que en el imaginario popular chileno esa figura nombra a un "ser maléfico, deforme y contrahecho, que lleva la cara vuelta hacia la espalda y anda sobre una pierna por tener la otra pegada a la nuca". Se cuenta, asimismo, que los brujos robaban a los niños y les obstruían los agujeros naturales del cuerpo, convirtiéndolos en imbunches con el objeto de guardar tesoros escondidos (cfr. Real Academia Española).

En el poema de Del Río, sin embargo, no son los brujos los que fuerzan el maleficio de aquel cierre, sino que es ejecutado por la propia hablante como una forma de resguardar los recuerdos que posee y que son acechados por los viejos guerreros. Desde su identificación con el imbunche, se convierte en una celadora de la memoria, a la que protege mediante el bloqueo que le permite esa figura deshumanizada, fragmentada y 
sellada. Así, ese niño condenado a guardar tesoros escondidos puede ser leído, en el texto, como el espejo de una niñez que contiene historias que deben ser resguardadas hasta el momento en que sea posible su emergencia. Dice el poema:

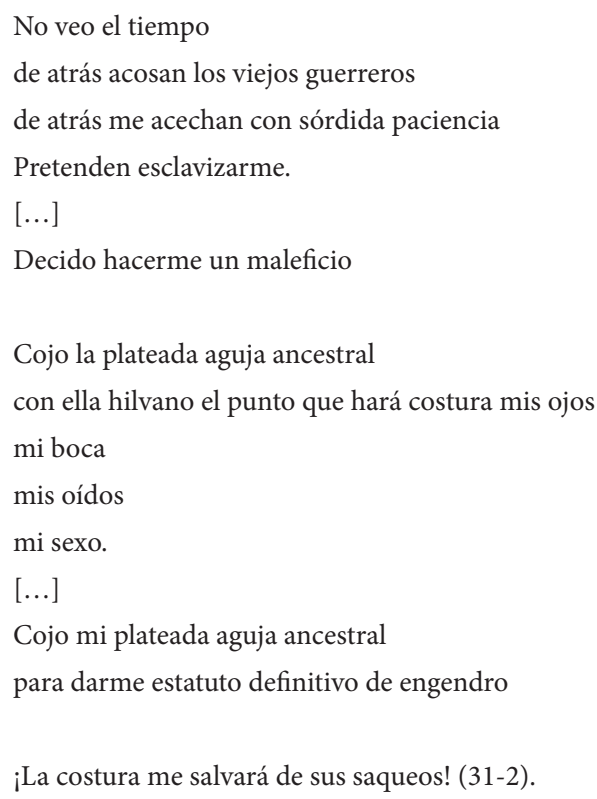

Esta sujeto-imbunche, dibujada como un ser contrahecho que se repliega sobre sí mismo, reaparece también en otros poemas del libro. Es lo que sucede, por ejemplo, en "Rangoon 2000", texto emparentado con las residencias nerudianas, donde la hablante refiere, primero, a cómo los objetos escapan de ella y, enseguida, al deber que se autoimpone de ordenar destrozos e hilvanar forados, como aludiendo a la necesidad urgente de proceder a una sutura provisoria sobre los huecos de una experiencia herida. De esta forma, tensionada entre su pulsión y su inmovilidad, organiza ansiosamente aquellos fragmentos y ruinas, obedeciendo a un designio moral que se sugiere en el tono autoimperativo de los verbos utilizados en el poema (“debo ordenar", "debo hilvanar"):

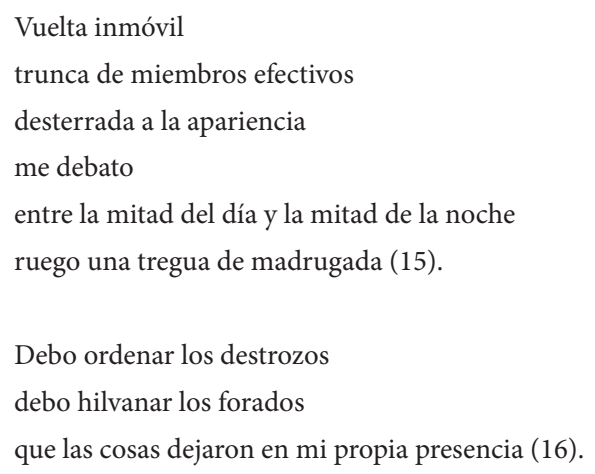


Por su parte, el poema "El colgado del tarot" ofrece otra imagen que revierte el gesto retentivo de la guarda que se resaltaba en el imbunche para enfatizar, en cambio, la opción por desprenderse de ideas y condicionamientos arcaicos. Este intento está representado en la figura del colgado de la cartomancia que, en su posicionamiento invertido, simboliza el deseo de una mutación radical, que conlleva dolor e incluso el autosacrificio de quien sufre en silencio para no hacer sufrir a los demás, pero que ofrece la alternativa de una transformación igual que lo que esa figura representa, la hablante se abandona a la vivencia de cambio, que tiene como campo de experimentación el propio cuerpo y a la que describe con imágenes que recuerdan los descendimientos mistralianos. A este proceso se entrega sin resistencia y como atendiendo al vaticinio de un futuro feliz, que traduce visualmente en el gesto de colgar hacia abajo y en el deseo de descansar sobre la tierra que acoge y vivifica, lo que produce al mismo tiempo una apertura en la conciencia:

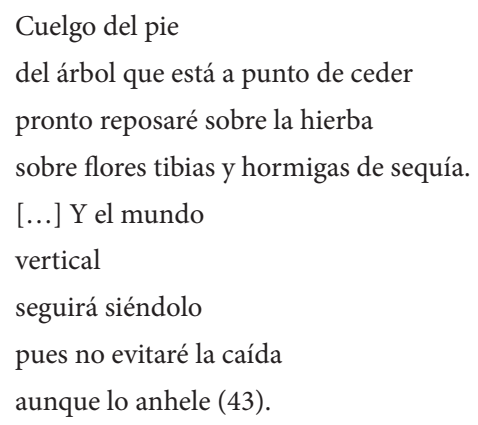

Me abro y entiendo/ es inevitable (49).

Tanto la figura del imbunche como la del colgado remiten, en definitiva, a una voluntad de hacerse cargo de la propia vida y de reconstruirse removiendo las ruinas de un pasado estancado y recurrente. Para ello, la hablante lleva a cabo un movimiento de descenso hacia el interior de sí, alejándose de la cabeza y bajando por el cuerpo hacia la tierra, proceso análogo al trabajo de las hormigas, que se entierran en tiempos de sequía. Por otro lado, de esta manera ella parece querer dejar atrás aquellos miedos y obsesiones que, desde la mente al cuerpo, bloquean la posibilidad de sobrevida. Como se sugiere en otro poema, titulado "Solo el decapitado sobrevive":

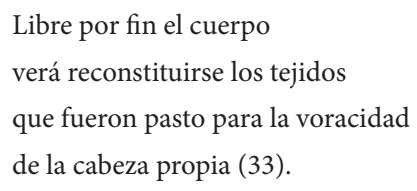

Habiendo pasado por "La mesa" y "La mano", secciones donde la hablante materializa un espacio de productividad escritural y simbólica, la tercera parte del libro, titulada "Los pies", agrega una metáfora que alude tanto al primer e ineludible contacto de la hablante con la tierra como a la base que le resulta necesaria para encarar su recorrido memorioso. 
Esta sección incorpora una serie de poemas que hacen eje en torno a las imágenes del viaje, el movimiento y la llegada a una tierra prometida (Sión), a través de un trayecto que, como refiere Lorena Amaro, implica un vagabundeo en pos de ciudades reales y poéticas. Por nuestra parte, considerando el sentido del recorrido de la hablante, también leemos esas imágenes como indicios que anuncian la escena de retorno, que se hará efectiva poco después. Esta vuelta al hogar familiar, y al origen de la identidad poética, se concreta en los poemas "Simultánea y remota" y "Resiliencia", en los que la hablante da forma a la imagen-recuerdo aterradora de una infancia vivida en dictadura.

El primero de estos poemas se articula como una rememoración de la hablante adulta respecto de su pasado infantil y se inicia con un vuelta al gesto iniciático de guardar restos, ya referido en el imbunche, que trasmuta en la acción de ocultar en una cajita unas alas de mariposa y antiguos conjuros de la piedra de Rosetta escritos con limón. Esta imagen, a través de la referencia a esa antigua inscripción textual, muestra, por un lado, la emergencia en la hablante de una poesía temprana que asocia con una de las preguntas nerudianas: “ppor qué se suicidan las hojas/ cuando se sienten amarillas?” (65). Por otra parte, aquellas imágenes iluminan el anudamiento que se produce en la hablante entre escritura, historia y política, que cristaliza en una poética que no puede sino hacerse en estrecho vínculo con la memoria. Desde ese lugar de enunciación estético/ético/político, la hablante será capaz de conjurar ese recuerdo doloroso y desestabilizador, y traerlo al presente mediante las palabras con el objeto de resignificarlo:

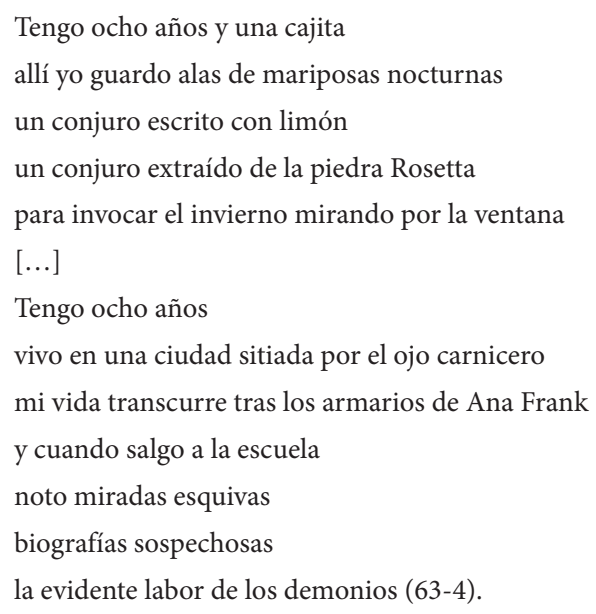

El proceso de rememoración que realiza la hablante en el poema se pone en acto desde una oscilación entre lo que se dice y lo que se calla, y entre pasado y presente, lo que supone un tránsito dinámico al que califica como una fidelidad. De este modo, uniendo a través de una misma voz los cronotopos que corresponden a la infancia y la adultez, ella va accediendo a la reparación que supone el recordar, es decir, a una cierta resiliencia que pasa por la aceptación del propio ser, de quien se es y quien se ha sido, lo que implica una posibilidad sanadora no solo para sí, sino también para la comunidad a la que pertenece: 


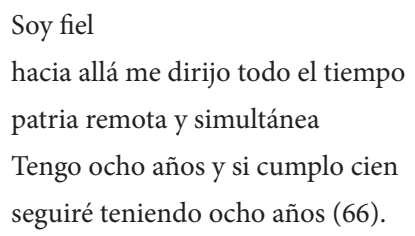

El final del poemario nos entrega a una hablante que, habiendo concluido un arduo recorrido interior y sabiéndose ya una eterna exiliada de su país y de su lengua, no desea permanecer de manera definitiva en ningún lado. Asumiendo otro posicionamiento subjetivo, deja atrás a la figura de la niña doliente para mutar en la de una madre que inicia un nuevo viaje junto a su hijo. De este modo, repitiendo el gesto del colgado de la cartomancia, suelta al niño para que pueda iniciar su propio recorrido vital; una acción que a ella misma le permite comenzar un nuevo andar sobre la tierra, que será, al mismo tiempo, una nueva exploración poética:

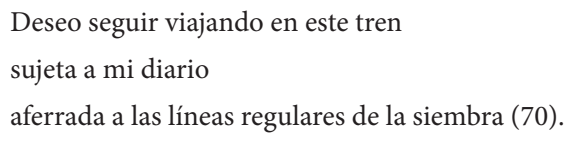

\section{Conclusiones}

A lo largo de estas páginas recorrimos los textos de Antonia Torres y Alejandra del Río, observando cómo se configura en ellos la relación entre memoria poética e infancia. Como procuramos demostrar, Torres y del Río comparten una serie de rasgos escriturales que tienen que ver, por un lado, con las condiciones sociales, culturales y estéticas que rodean la producción de sus textos, y por otro, con las características de las poéticas que elaboran, a través de las cuales se hacen cargo de ciertos duelos personales y colectivos.

En ambos poemarios lo que queda de manifiesto es eso que, con ayuda de Gilda Waldman, podríamos denominar posmemorias poéticas, es decir, la creación de lenguajes estéticos donde se acogen discursos que remiten a sujetos cuyas infancias y primeras juventudes se vieron marcadas por el impacto de la dictadura cívico-militar de Augusto Pinochet, así como por las múltiples secuelas individuales y colectivas que aquella proyectó sobre el periodo posterior. Muertes, desapariciones, miedo y soledad, pérdida del sentido comunitario, crisis familiares y personales, son vivencias que se cuelan y metaforizan en imágenes tales como el naufragio y las ruinas (Torres) o la cajita que guarda preciosos objetos de una niñez aterradora (del Río) y que se combinan con otras que remiten a niños huérfanos o abandonados, pequeñas imbunches e infancias desvalidas.

Junto con estas imágenes, no obstante, también emergen otras representaciones que nos devuelven a las hablantes, ya adultas y en tránsito constante, en el proceso de reconectarse con esas vivencias pasadas. Mujeres que, maniobrando con sus recuerdos, buscan en la creación poética modos posibles de lidiar con aquellos duelos pendientes. 
Para las sujetos que se escenifican en estas escrituras, esas elaboraciones son promovidas por la realización de prácticas y rituales que suelen llevarse a cabo en relación próxima con el mundo natural (inmersiones, descensos hacia lo profundo de la tierra). De estas experiencias ellas resurgen con una conciencia renovada y adoptando una posición distinta frente al propio cuerpo, al que asumen ahora como el anclaje esencial desde el que es posible configurar una nueva subjetividad.

En definitiva, para una y otra autora, en uno y otro texto, esta posibilidad transformadora, entendida como la mejor alternativa de sobrevida, no puede sino ocurrir en el terreno de (y a través de) la poesía, voz-cuerpo y voz-comunidad en la que se deposita una cierta confianza (jamás plena) en la posibilidad de suturar no solo las heridas íntimas, sino también aquellas que pesan sobre el vínculo social.

\section{Referencias}

Amaro, Lorena. "La enfermedad del regreso. Material mente diario, de Alejandra del Río". La Calle Passy 61. Literatura y crítica literaria contemporáneas. 15 de septiembre de 2009. <http://lacallepassy061.blogspot.com/2009/09/la-enfermedad-del-regresomaterial.html $>$. Fecha de ingreso: 30 de junio de 2012. Sitio web.

Bello, Javier. "Los náufragos". <http://www.uchile.cl/cultura/poetasjovenes/naufragos1. htm $>$. Fecha de ingreso: 30 de junio de 2012. Sitio web.

Consulta cartas. Sitio web Tarot. <http://www.consultacartas.com/carta_tarot_el_colgado. html $>$. Fecha de ingreso: 30 de junio de 2012. Sitio web.

del Río, Alejandra. Material mente diario, 1998-2008. Santiago de Chile: Cuarto Propio, 2009. Medio impreso.

Genovese, Alicia. "Entre la ira y el arte del olvido: testimonio e imagen poética”. Recordar para pensar. Memoria para la democracia. La elaboración del pasado reciente en el Cono Sur de América Latina. Ed. Tania Medalla, Olga Ruiz y Alondra Peirano. Santiago de Chile: Böll Cono Sur, 2010. 69-76. Medio impreso.

---. Leer poesía. Lo leve, lo grave, lo opaco. Buenos Aires: FCE, 2011. Medio impreso.

Halbwachs, Maurice. Les cadres sociaux de la mémoire. 1925. <http://classiques.uqac.ca/ classiques/Halbwachs_maurice/cadres_soc_memoire/cadres_sociaux_memoire. pdf $>$. Fecha de ingreso: 21 de enero de 2013. Sitio web.

Jelin, Elizabeth. Los trabajos de la memoria. Madrid y Buenos Aires: Siglo XXI, 2002. Medio impreso.

Lange, Francisca. Diecinueve: (poetas chilenos de los noventa). Santiago de Chile: JC Sáez, 2006. Medio impreso.

Monteleone, Jorge. "Poetas en la mitad de la vida”. La Nación 24 de octubre de 2009. $<$ http://www.lanacion.com.ar/1188416-poetas-en-la-mitad-de-la-vida >. Fecha de ingreso: 27 de enero de 2011. Sitio web.

Moulián, Tomás. Chile actual. Anatomía de un mito. Santiago de Chile: Arcis-Lom, 1997. Medio impreso. 
Real Academia Española. Sitio web diccionario de la lengua española. $<$ http://www.rae. es/rae.html>. Fecha de ingreso: 30 de junio de 2012.Sitio web.

Ricoeur, Paul. "Historia y memoria. La escritura de la historia y la representación del pasado". Historizar el pasado vivo en América Latina. 2007. <http://etica.uahurtado. cl/historizarelpasadovivo/es_contenido.php $>$. Fecha de ingreso: 21 de enero de 2013. Sitio web.

---. La memoria, la historia, el olvido. Buenos Aires: FCE, 2000. Medio impreso.

Sepúlveda, Magda. "El territorio y el testigo en la poesía chilena de la Transición”. Estudios Filológicos 45 (2010). 79-92. <http://www.scielo.cl/scielo.php?pid=S007117132010000100007\&script=sci_arttext $>$. Fecha de ingreso: 21 de enero de 2013. Sitio web.

Torres, Antonia. Las estaciones aéreas. Valdivia: Barba de Palo, 1999. Medio impreso.

---. “Las estaciones aéreas”. Inventario de equipaje. Santiago de Chile: Cuarto Propio, 2006. Medio impreso.

Véjar, Francisco. Antología de la poesía joven chilena. Poesía de fin de siglo. Santiago de Chile: Universitaria, 1999. Medio impreso.

Waldman, Gilda. "Post-memoria: una primera aproximación". Memorias (in)cógnitas. Contiendas en la Historia. Ed. Maya Aguiluz y Gilda Waldman. México D.F.: Universidad Nacional Autónoma de México, 2007. 387-99. Medio impreso. 